\title{
Interactive comment on "Climatology of the mesopause density using a global distribution of meteor radars" by Wen Yi et al.
}

\section{Wen Yi et al.}

yiwen@ustc.edu.cn

Received and published: 9 March 2019

This is a manuscript with track change. Please download supplement pdf.

Please also note the supplement to this comment:

https://www.atmos-chem-phys-discuss.net/acp-2018-1040/acp-2018-1040-AC3-

supplement.pdf

Interactive comment on Atmos. Chem. Phys. Discuss., https://doi.org/10.5194/acp-2018-1040, 2018. 